\title{
THE ETHNOMATHEMATICS OF TUTUWARU COMMUNITY IN THE CRAFTS OF KOLI LEAF WEAVING
}

\author{
Theresia Laurens ${ }^{1 *}$, Rudolf Kempa ${ }^{2}$, Henderika Serpara ${ }^{3}$ \\ ${ }^{1,2,3}$ University of Pattimura, J1. Ir. M. Putuhena, Poka-Ambon, Maluku, Indonesia \\ e-mail: ${ }^{1}$ tresyalorensa@yahoo.co.id; \\ Revised: December 30, 2020 \\ Accepted: December 31, 2020 \\ corresponding author*
}

Submitted: August 8, 2020

\begin{abstract}
Ethnomatemics-based mathematics concept implementation can be carried out through constructivismbased learning such as realistic mathematics, problem-based and learning with a scientific approach. This research purpose to explore the form of ethnomatemics on the woven cabbage leaves of the Tutuwaru community and analyze the process of understanding mathematics from the perspective of indigenous people and indigenous knowledge and examine the development of woven form ethnomatatics in school mathematics. The method used in this research is descriptive qualitative research. The subjects are 2 members of the weaving community, while the objects of research are Nyiru (winnowing-basket), Topi (hat), Keranjang dan Bakul (basket). The results showed that the form of weaving from a typical local Koli (cabbage) tree, could be connected with several mathematical concepts such as basic geometry and arithmetic. The hexagonal concept based on the understanding of multiples is an "indegious knowledge" that exists in the Tutuwaru community in constructing the form of nyiru-woven, reflection, points, lines and tessellation. These mathematical ideas can be used as context in school mathematics learning
\end{abstract}

Keywords: ethnomatematics, woven koli leaves, school mathematics

\section{Introduction}

The role of mathematics is very important in shaping rational thinking processes so that mathematics is required in the school curriculum. However mathematics is still considered difficult for some students as well as teachers. This is because mathematics learning often begins with a formal approach, even though mathematics is a human activity (Hadi, 2017). In daily life, Mathematics has been indirectly used by the community.

Indigenous people in their activities have used mathematical ideas, for example in making transactions or making objects used to meet their daily needs, and this has become a habit of going down Heredity, which shows the culture of the surrounding community that is associated with mathematical concepts known as ethnomatematics. Ethnomatematics is mathematics that grows and develops in a particular society's culture (D'Ambrosio, 2001, Rosa \& Orey (2007)).

By utilizing students'experienced and relate them to the mathematical concepts will create the benefits of learning mathematics. In the culture of Maluku people are known by some local wisdom such as masohi culture which shows the values of kinship, togetherness, how to sell in the market by piling up selling goods (gandariah fruit, langsat fruit, fish, etc.), patterns of woven products, woven products, results of processing clay in the form of geometry and others.

The habit of selling by using the "piling" model indirectly has shown the concept of assembly. (Laurens, 2017). In addition, the people of Southwest Maluku usually make plaits to ward off corn, commonly called "nyiru" and plaques for lifting food such as corn and beans, called "bakul" having the basic ingredients of koli leaves (a type of palm leaves).

By observing the patterns of life that exist unconsciously, people have used the concept of tiling in arranging the weaving, likewise in coloring the matting they unconsciously have used the concept of reflection.

The construction of woven objects and sharing variations of letters, the ideas of flat shapes and even flower variations that are colored using natural dyes are the hallmark of the Koli woven from Tuturwalu community, which have been studied for generations. Therefore, the problems in this study are formulated as follows: (1) how is the form of ethnomatematics on the cabbage leaf weaving in the Southwest Maluku Tutuwaru community, (2) What are the mathematical concepts that can be learned in the Tutuwaru community's cabbage leaf weaving. 
This research aims to explore the form of ethnomatemics on the woven cabbage leaves of the Tutuwaru community and analyze the process of understanding mathematics from the perspective of indigenous people and indigenous knowledge and examine the development of woven form ethnomatatics in school mathematics.

\section{Ethnomatematics}

The reality of human life is inseparable from culture and local wisdom. Local wisdom provides a variety of possibilities for the emergence of knowledge arising from the natural thinking of the local community. This natural thinking gives rise to creative thinking that is manifested in various objects and habits that become a hereditary tradition. The ability to compile material or numerical ability is the ability to think that is not formed as a formal learning process. The link between culture and spatial ability or numerical ability gave rise to the term ethnomatematics. Literally, the term ethnomatematics is a series of ethno and mathematical words that have a relationship between culture and spatial ability or numerical ability (D'Ambrosio, 1990, Rosa \& Orey, 2007, 2011, Zhang \& Zhang, 2010). In line with the context where indigenous people who do not recognize numbers can carry out the operations of addition, multiplication and division, and can even assemble natural materials from the surrounding environment into space buildings that have links with geometrical ideas. The function of Ethnomatematics is to express the relationship between culture and mathematics or ethnomatematics is seen as a science that is used to understand how mathematics is adapted from a culture (Marsigit, 2016). Thus, it should be shown that in daily life students are familiar with mathematics or can be said that mathematics useful in everyday life. Hence, if the students experienced the benefits of mathematics then by themselves they will be motivated to learn mathematics.

In relation to pedagogy, ethnomatematics can be studied in philosophy and the history of mathematics. Ethnomatematics can be developed in the field of Education and learning to show how mathematics has a relationship with the reality of human life (Rosa \& Orey, 2007, Chieus, 2004, Damazio, 2004). Some terms used to understand ethnomatematics are indigenous mathematics (Gay \& Cole, Lancy), sociomathematics (Zaslavsky), informal mathematics (Posner, Ascher \& Ascher), mathematics in the socio-cultural environment (Doumbia, Toure '), spontaneous mathematics ( D'Ambrosio), oral mathematics (Carraher, Kane), oppressed mathematics (Gerdes), non-standard mathematics (Carraher, Gerder, Harris), hidden or frozen mathematics (Gerdes), folk mathematics (Mellin-Olsen), people's mathematics (Gellin) Julie) and mathematics codifies in know-how (Ferreire), (Mampouw, 2010). By paying attention to the wide scope of ethno-mathematics, of course in understanding local wisdom, ethnomatatics can be explored for the benefit of learning development.

\section{Local Wisdom of Tutuwaru Community}

As part of the Maluku archipelago which has thousands of islands, including the Tutuwaru people who live within the territory of the Southwest Maluku government, in general have some cultural characteristics that are almost the same as other Maluku communities.

Maluku people are spread in large and small islands with a total about 1400 islands with a population around 1,533,506 people and have the main language of Ambon Malay and 140 other local languages with a variety of regional cultures. Natural resources in Maluku provide opportunities for Maluku people to buy and sell crops freely in accordance with land ownership and search sources. The way to sell with the habit of grouping, counting, measuring, designing buildings or tools, and playing, is the goal of ethnomatemics according to Wahyuni in Zusmelia (2016).

Traditionally in daily activities, Maluku people have a habit of selling by stacking what is sold on a table or a stretch of land on the edge of a road or on a sidewalk. The stack is adjusted to market prices so that it varies greatly in quantity and price. For example, the habit of selling fish by grouping several tails in one pile (by the people of Maluku is called satu tas (one bag) or satu tampa (one portion) or satu tali (one rope)). The variation in the number of fish in a pile is very dependent on market conditions and the current sea situation. Usually in a pile there are three, four or five or even more fish with different sizes according to fish species. Likewise with the sale culture of Maluku typical fruits including rambutan, gandaria, langsat, duku, mangosteen and durian. (Laurens, 2016). In addition to fruits, the selling of traditional food including sagu lempeng, bagea and sarut made from sago-based ingredients, while embal or embal love (flower-shaped) made from cassava. The grouping or stacking of these objects indirectly indicates the assemblage concept.

In addition, they also need a variety of skills in processing and utilizing the environment needed to meet their needs among other household equipment needs. 
The Tutuwaru community has a variety of skills in making plaits from the leaves of the Koli tree which is a local tree of the local community as a container for collecting food crops. The matting can be used to reject corn, and it is called matting called "nyiru" and matting to pick up garden food such as corn and beans called "sesre" or "bakul (basket)". (Laurens, 2018).

With a variety of local wisdom in Maluku, of course, perspectives on life patterns differ from one another according to the local culture. In relation to mathematics, then to study ethnomathematics is certainly based on the perspective of a group of people in a particular culture that has knowledge of local wisdom known as indigenous people. Typical knowledge possessed by a group of people in carrying out activities, counting, grouping or designing a tool known as indigenous knowledge. By paying attention to the patterns of life or habits that exist unconsciously, the community has used the concept of assemblage, tile, and reflection, and may even still exist other mathematical concepts that can be explored through community culture. Culture, traditions and symbols are manifested in everyday people's lives including mathematics education (Fouze \& Amit, 2017). If learning mathematics is associated with a culture that grows and develops in society, students will feel they have mathematics, so that they will be interested in learning it. (Fouze \& Amit, 2017).

\section{Ethnomatematics in School Curriculum}

The role of ethno-mathematics as a new concept in bridging mathematics and culture provides an opportunity for the world of education, to include ethno-mathematics in the school curriculum. This is due to the fact that the school curriculum has been academic in nature and has not emphasized the benefits of mathematics in everyday life (Matang, R. 2002).

Through exploring the local wisdom of the Maluku people and linking them to the mathematics content and integrating it in learning, students are expected to recognize and appreciate their culture (Laurens, 2016). Therefore it is important to study the mathematical values that naturally grow and develop in society and develop them in learning through the school curriculum (D'Ambrosio, 1998, Widada, et al, 2018, Matang, 2002, Isabela, M, 2019). The accompaniment result of this development is that students will love the culture of their region as a form of their love of the Indonesian nation. This requires the teacher to understand the local community's local wisdom. Teachers who do not understand the meaning of local wisdom tend to be less sensitive to the diversity of local culture. Another obstacle that usually arises is teachers who experience a lack of skill, consequently less able to create learning that respects the diversity of regional culture (Marlupi, 2011).

Based on previous research studies on the development of local wisdom-based mathematics learning towards students' character, it is known that there are differences in learning outcomes between the experimental class and the control class. The accompanying impact is that there is an increase in understanding of the values of national love characters such as knowing traditional foods, the term soa and the values of accuracy, cooperation, and responsibility (Laurens, 2016). These studies indicate the need to integrate local wisdom in learning, which is preceded by identifying cultural values that exist in society and mapping them with mathematical concepts. Therefore, it can be developed in learning and curriculum.

Ethnomatematics in school curricula provides opportunities for the development of knowledge, attitudes and skills as abilities students must have. This capacity building must be planned in a written document in the form of a learning plan that contains methods, strategies and learning approaches. Learning planning that is carried out must provide opportunities for students to construct knowledge by linking it with prior knowledge and experience (Francois \& Pixten, 2011). Thus, ethnomatematics as part of culture and mathematics is important to be developed in the curriculum. In the 2013 curriculum which emphasizes the use of a scientific approach in learning, provides opportunities for teachers to associate culture with mathematics. The people in Maluku in general has a culture of dance, weaving and buying and selling activities that are somewhat different from other communities in Indonesia.

\section{Research Method}

\subsection{Research Design}

This research has been conducted using qualitative research because it reveals what happened in this study about the problems that occur, answering direct questions posed, examining the results of research involving symbols that are used also as a society. This Research conducted on people who have a weaving culture. The chosen location was Tutuwaru Village, Letty District, Southwest Maluku Regency. The subject of the study was the woven craftsmen community consist of 2 women. The core 
instrument of this research is to compleate interviews and observation sheets, recording devices and field notes.

The data in this study were obtained using non-test techniques namely documentation, observation and interviews. Documentation is used to explore information about symbols (for example or words or sentences that have occurred in writing or other phenomena that can be documented when collecting data (photos, videos) or observations while at the research location. Observation techniques are used to observe activities and ways to produce cultural products such as making objects or game tools or other traditional tools. Interview techniques are used to obtain data about indigeous knowledge about the processes or activities that produce cultural products.

\subsection{Research Procedure}

This research was carried out with the following steps: 1 . Reviewing various literature on ethnomatematics including research conducted by Francois (2009), Zhang \& Zhang (2011), Laurens (2016), Mampaouw, (2012), Matitaputy, (2016) ), Marsigit, (2016) and Zusmeida, (2016), Ngilawayan (2016) about learning mathematics based on Maluku local wisdom and ethnomatematics in several communities including Timor, Minangkabau and Java .; 2. Formulate research problems on how ethnomatematics of Southwest Maluku Tutuwaru community whose solutions are sought starting from the planning, implementation and evaluation stages in order to obtain answers to the problems studied; 3 . Develop interview guidance instruments and prepare other supporting instruments; 4. Prepare a research schedule and arrange for a research permit; 5 . Prepare the team for data collection; 6. Go to the research location; 7. Coordinate with the village head; 8. Conduct data collection processes; 9. Analyze data; 10. Prepare research reports.

\subsection{Data Analysis Technique}

The collected data were analyzed using qualitative data analysis techniques according to Moleong (2009), namely the process of reduction, by reducing or eliminating non-essential data, then performing data in the form of narratives or tables or graphs and making conclusions. In order to prove the validity of the data triangulation process is carried out both with the source and method.

In this research the reduction process is carried out through the sorting of informant data that is considered not in accordance with the objectives of the study, for example the answers of informants who are not the focus of research. The reduced data is then presented in a narrative form that describes the perception of the people in weaving. The triangulation process is carried out to obtain valid data by triangulating the source by interviewing other informants to obtain comparative data.

\section{Results and Discussion}

Ethnomatematics in the process and products of nyiru, caps and basket as a result of koli (cabbage) leaf plaited

Through natural processes, people process cabbage leaves into a number of useful tools for their daily lives.

\section{Weaving preparation process}

Making various forms of woven has been carried out since their ancestors. Data obtained from the village head (LS) that not all people know the process of making weavings, only a few types of weavings are still made by some craftsmen whose age is around 50 or older. One of the subjects that the informant teaches in this study is Ny.NS who still controls almost all of the process of making webbing, from simple to making fans, mats to making hats. Following are excerpts of the interview with NS.

\begin{tabular}{|c|c|c|}
\hline $\mathrm{P}$ & & $\begin{array}{l}\text { Apakah semua daun dapat dijadiakn bahan } \\
\text { baku pembuatan anyaman? } \\
\text { Can all the leaves be used as a raw material } \\
\text { for woven making? }\end{array}$ \\
\hline NS & & $\begin{array}{l}\text { Tidak bisa semua mama, karena katong } \\
\text { (kita) musti ambil daun yang masih muda, } \\
\text { kayak (seperti) ini (menunjuk daun } \\
\text { berwarna kuning muda yang sementara } \\
\text { digantung di bawah tiris rumah). } \\
\text { No madam, because we have to take young } \\
\text { leaves, like this (showing light yellow } \\
\text { leaves that are temporarily hung under } \\
\text { house' gutter }\end{array}$ \\
\hline $\mathrm{P}$ & : & $\begin{array}{l}\text { Mengapa harus di letakkan di bawah tiris. } \\
\text { why it has to be put there }\end{array}$ \\
\hline NS & : & $\begin{array}{l}\text { Itu angin-angin, seng boleh (tidak boleh) } \\
\text { kena panas. } \\
\text { So as to be exposed to the wind, it can't be } \\
\text { under sun }\end{array}$ \\
\hline $\mathrm{P}$ & & Kenapa? why? \\
\hline NS & & $\begin{array}{l}\text { Karena nanti dia patah-patah, keras, zeng } \\
\text { bisa atur. } \\
\text { Because it will broken, hard, and } \\
\text { unmanageable }\end{array}$ \\
\hline
\end{tabular}

So before weaving, leaves are taken down from the tree by selecting leaves that are still young, dried by opening and hanging in a place that is not exposed to sunlight, after that it is only processed to get the materials for making matting. The processing process is explained as follows:

$\mathrm{P}$ : Setelah kering, selanjutnya bagaimana? After dry, whats next? 
NS : Daun dikeluarkan dari tulang daunnya, kemudian disayat (potong dengan pisau yang tajam) kecil-kecil dengan lebarnya sesuai kebutuhan. Kalau mau yang halus daunnya dibuat ukuran kecil, kalau mau yang kasar dibuat yang besar.

The leaves are removed from the bone of the leaf, then sliced (cut with a sharp knife) into small pieces as wide as needed. If you want something delicate, the leaves are made of small size. if you want a rough one, make a big one

$\mathrm{P} \quad$ : Maksudnya potongan halus dan lebar?

You mean, smooth and wide pieces?

NS : Iya mama, kalau halus akang pung hasil teratur (maksudnya rapih) sama topi deng nyiru.

Yes madam, if its smooth, the result is neat, same with hat and nyiru

The results of this interview indicate that for the manufacture of wicker, people have thought about the results of the relationship of the material prepared with the results obtained. In addition they also understand the leaf construction that will be used.

The next data is the thought process that is used in making their plait and natural knowledge which is associated with mathematical concepts.

\section{The process of making nyiru woven and hats}

Nyiru in Letty (Tutuwaru) is called "totope". Nyiru is used as a means of mixing corn or beans or other dry food ingredients. The process of making nyiru begins by taking 6 pieces of sliced cabbage leaves, then weaving to get 6 angles, then weaving to form a base and adding 12 pieces then weaving again to form 12 angles, and so on, so as to achieve the desired amount of nyiru. Some of these can be seen in the following picture:
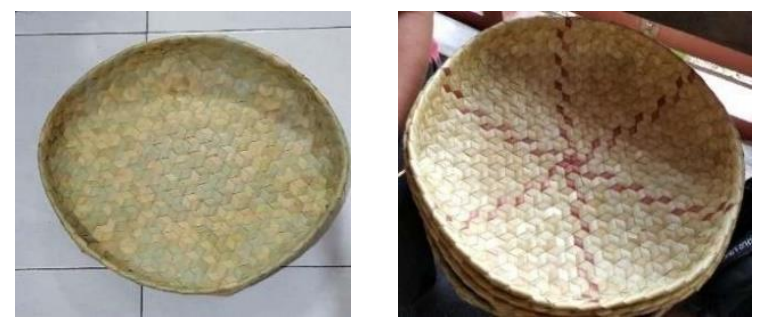

Figure 1. Nyiru form without variation and using variations of colored leaves

To find out the process of making, here is the interview passage with one of the craftsmen.

\footnotetext{
$\mathrm{P} \quad$ : Mama tolong bilang bagaimana memulai membuat nyiru ini

Madam, please tell me how to start making this nyiru

NS : Katong (kita) mulai dengan mendudukkan dasarnya dengan mengambil 6 potong daun kemudian buat seperti ini, menunjuk
}

cara membuatnya. Ini katong anyam sampe dapat dia pung susu (maksudnya pojoknya=titik sudutnya) kemudian katong tambah daun lagi.

We started by sealing the base by taking 6 pieces of leaves then making it like this, pointing out how to make it. We weaves untul we get Susu (the corner) then we add more leaves

$\mathrm{P} \quad$ : Berapa daun yang harus ditamba?

How many leaves to add?

NS : kalau tadi 6, katong ambil lagi untuk anyam jadi besar katong musti ambil 12

If it was 6 , we need to add 12 for bigger woven

$\mathrm{P} \quad$ : Kalau ambil 5 bagaimana?

What if we took 5 ?

NS : seng bisa mama musti 12 kalau seng (tidak) dia sawai (maksudnya bengkok), seng bagus.

You can't madam, it has to be 12 . Otherwise it will bent

$\mathrm{P}$ : Coba anyam terus. please keep weaving

NS : (sambil mengayam) Kalau su tadudu (maksudnya sudah menemukan bentuk dasar), anyam tuh gampang, tinggal ikuti saja, kalau su dapa susu (maksudnya titik sudut, katong tambah daun lagi

(While weaving) if it has formed a base, it will be easy to weave. just follow it, if you have found susu (vertex), add more leaves

$\mathrm{P} \quad$ : Berapa daun lagi?

how many more leaves?

NS : supaya susu 6, daun musti 12, berarti, kalau dapat susu 12 katomg tambah 24 daun.

To make 6 susu, must be 12 leaves, means, if we have 12 susu, we add 24 leaves

P : Terus kapan berhenti tambah daun?

So, when to stop adding leaves

NS : Kalau mau besar tambah tapi biasa itu cuma 7 mata saja (menghitung dari titik pusat ke ujung (akhir) anyaman sampai tujuh daun terlewati.

If you want bigger you can add more. But usually only 7 susu (count from the center to the end of woven until seven leaves are passed.

The information above shows that to weave nyiru we need a calculation process based on the numbers $6,12,24,36$, and so on.

In general, the mathematical patterns obtained are multiples of 12 , and also the geometrical shape with the basic pattern of the starshaped shapes which they called it "mata angin" (points of compass), which will form a regular hexagon when connected at an angle. Basic woven that will be developed in the shape of a star like the following picture. 


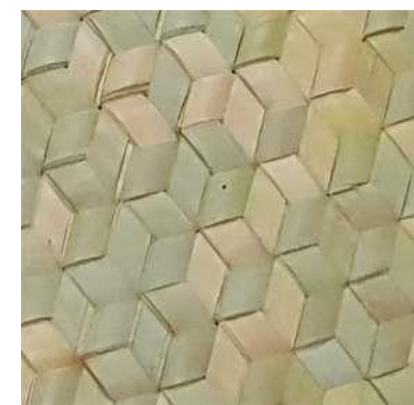

Figure 2. Basic woven cabbage (koli) leaves

Besides nyiru there are woven hats that have the same basic manufacture as nyiru, which requires 12 leaves to get the base of the matting, and subsequently has a rather different manufacturing process and requires a rather complex thought process. The following is an example of woven hat or in the language of the Tutuwaru region called "Tutulu".
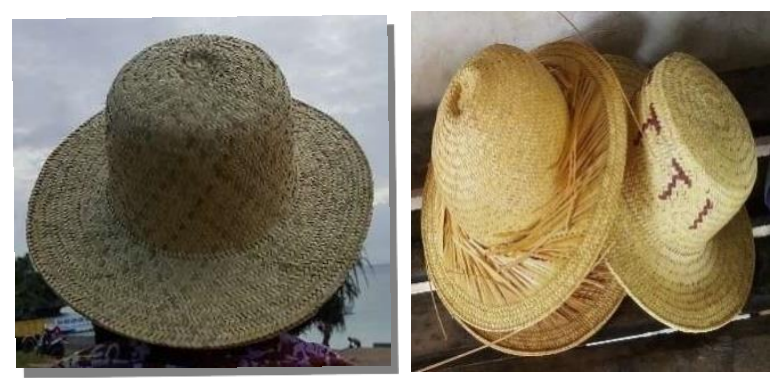

Figure 3. The forms of the hat

Woven hats or "tutulu" use the basic ingredients of leaves whose incisions are smaller than leaf incisions for nyiru. The shape of the incision is intended to get neat and good looking results. The basic ingredients of young cabbage leaves (or shoots of cabbage trees) are dried by aerating (drying without direct sunlight). In general, the manufacturing process follows the basic of making a copy, but the way weaving is different, slightly follows the shape of the human head. The following are excerpts of interviews about the process of making hats.

\footnotetext{
$\mathrm{P} \quad$ : Mama coba jelaskan bagaimana awal pertama membuat topi

Madam, can you please explain how to start making hats?

NS : Sama dengan nyiru, membutuhkan 12 daun pertama untuk membentuk dasar anyaman, dari 12 daun tadi akan membentuk 6 susu (6 sudut)

Similar with nyiru, first, we need 12 leaves to form the basic woven. From that, it will form 6 susu (corners)

$\mathrm{P} \quad$ : Tetapi khan bentuknya tidak sama dengan nyiru

But, the form is not similar to nyiru

NS : Dasarnya sama, cuma setelah dasar anyamannya. karena topi kan bulat, beda dengan nyiru. Pertama bentuk dia lalu
}

buat susu untuk bentuk kepala, habis dasar hitung 1 mata dolo, habis anyam ke depan lagi harus 3 mata, 4 mata, sampa 8 mata. kalau seng (tidak) dia seng bagus. Selesai 8 mata baru bentuk yang turun (maksudnya sisi lengkung), dari 8 tinggal anyam, kalau sudah itu pakai tulang daun (menunjuk leher topi),

Basically the same, only after the basic weaving. because the hat is round, it's different from Nyiru. First form it, then make susu for the shape of the head, finished base count 1 eye, the following must be 3 eyes, 4 eyes, until 8 eyes. otherwise it's not good. Finish 8 eyes, then form down (meaning the curved side), of the 8 weaving, we use the bone of the leaf (pointing to the neck of the hat),

P : Kalau di sini (maksudnya leher)tulang itu di ukur lagi

From this (meaning the neck) the bone is measured again?

NS : itu pakai ukur, ukur saja mengikuti lingkar ini (maksudnya mengikuti besarnya leher topi yang sudah terbentuk), lalu anyam saja.

It is, just measure to follow this circle (meaning follow the size of the neck of a hat that has been formed), then just weaving.

This information shows that in the process of making caps, in addition to being calculated, they also measure the length of the leaf bone by estimating the bottom circle of the cap tube blanket. In addition, the hats that are made can be combined with colored leaves to produce letters, flowers or other shapes. How do these forms occur, according to them automatically because they have seated the base of their webbing. The following results are explained:

$\mathrm{P} \quad$ : Tapi ini warna merah ini, bisa berbentuk bunga itu bagaimana?

But this red color, how can it be shaped like a flower?

NS : Karena dari pertama sudah buat dasar mata angin (enam sudut tadi). Jadi kalau anyam tinggal mengikuti saja, yang berwarna merah tetap akan berbentuk seperti ini (sambil menunjuk bentuk topi yang daunnya berwaran merah).

Because from the first had made the base of the wind (six angles earlier). So if we just follow it, the red one will still be shaped like this (while pointing to the shape of a hat with red colored leaves).

P : Daun warna merah ini memang asli atau bagaimana

Is this red leave indeed original or?

NS : Ini daun koli muda yang diwarnai dengan cara merebus 


These young koli leaves are colored by
boiling
P : $\quad$ Merebusnya pakai pewarna?
Boiled with coloring?
Bukan ini pakai daun jati (daun muda
pohon jati) yang direbus, kemudian
disaring dan airnya digunakan untuk
merendam daun koli, setelah itu daun koli
muda tadi dikeringkan dengan cara
dianginkan.
No, this uses teak leaves (young leaves of
teak trees) which are boiled, then filtered
and the water is used to soak the cabbage
leaves, after that the young cabbage leaves
are dried by aerating.

The interview above shows that in the weaving process there needs to be a calculation so that the base of the weave must make the shape of the wind. To get the shape of the basic flower of colored plaits earlier by itself will form a crossshaped arc of flowers with six angles as following shape:

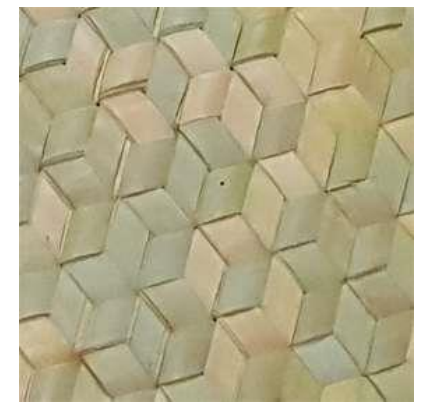

Figure 4. Hats with flower variations

Some forms of plaits that use koli leaves include sesre (basket) and baskets that use koli leaf bones which can be varied with the shapes of letters, shapes or others as shown below.
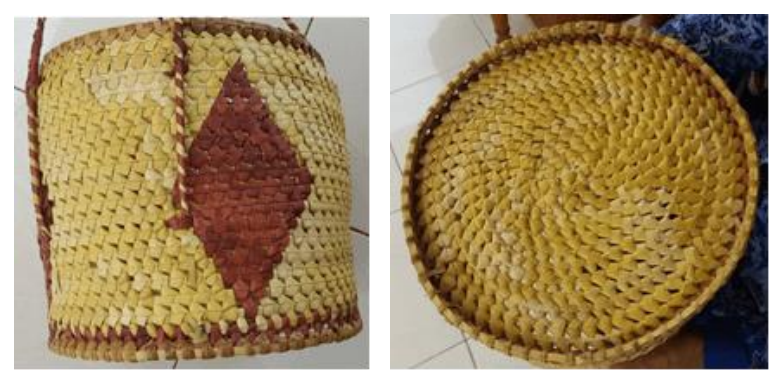

Figure 5. Baskets

How to make sesre (type of baskets) and baskets are different from hats and nyiru, because sesre and baskets use raw materials of cabbage leaf bone, while nyiru and caps use cabbage leaves. Note that in weaving there is already an idea of building space, which is a parallelogram. When asked how to weave so as to form an image on the curved side of the basket following the interview interview:

$\mathrm{P} \quad$ : Bagaimana cara buat sesre ini
How to make this sesre?

$\mathrm{R} \quad$ : Kalau ini agak beda akang pakae tulang lalu buat melingkar

If it's a bit different, use bone and make it circular

P : Kalau awal buat bagaimana

How about the beginning?

$\mathrm{R} \quad$ : Ambil daun dan buat dasar, ikuti lingkar tulang

Take the leaves and make a base, follow the bone circle

P : Kalau bisa bikin bikin warna sama dengan ketupat ini bagaimana

How to make the same color as the diamond (ketupat)

$\mathrm{R} \quad$ : Ini katong musti hitung

We have to count

$\mathrm{P} \quad$ : Caranya? How?

R : Mulai dari anyam 1, anyam 2, 3,4,5,6, sampai 7 , hitung lai $6,5,4$, sampai 1

Starting from weaving 1 , weaving 2, $3,4,5,6$, to 7 , counting again $6,5,4$, to 1

$\mathrm{P}$ : Kenapa musti sampai 7 hitung bale deng 6, mengapa zg 7 lai

Why we have to count until 7 then back to 6 , why not 7

$\mathrm{R} \quad$ : seng bisa ibu, musti 6, kalau seng akang seng bagus

You cannot. Must be 6, otherwise its not good

$\mathrm{P} \quad$ : Maksudnya seng bagus bagaimana

What do you mean by noot good?

$\mathrm{R}$ : dia bentuk seng sama, akang seng rata, bengkok.

It is not into the same shape, uneven, bent

This interview passage shows that the craftsman understands the concept of symmetry, meaning that after 7 it must be reduced to find the same pattern as the initial position when drawing.

\section{Analysis of mathematical concepts in woven structures}

Based on the analytical results of the results of the webbing above, it can be traced the use of mathematical ideas since the ancestors of this society existed. From the results of interviews with them, it can be seen that the process of making webbing is especially misty, using many leaf pieces with multiples of numbers $12,24,36, \ldots$, besides that they also indirectly use geometrical ideas such as the vertex which in their concept is called susu (breast). The term susu is coupled with the shape of the nipples in a rather prominent shape, they don't call it angles or jiku but call it susu (breast). In the structure of nyiru woven there is a basic woven with the shape of the "mata angin" (points of compass). which can be connected to the vertex forming a regular hexagon. These regular hexagons in mistaken form can be widened (dilated ideas) into larger hexagons by paying attention to 
the distance of the leaves which they call the term "mata". The following forms the basic structure of woven nyiru with the basic shape of a regular hexagon or contains 6 triangles that are equal in size to the leaf count pattern is 1 , in, 3 out, 1 in, 3 out, so the pattern used is $1,3,1,3, \ldots$ up to 1 .



Figure 6. The structure of nyiru is woven with 6 susu



Figure 7. Regular hexagon

Picture 6 is a picture of matting with 6 susu or 6 corners. If this blueness is abstract, a regular hexagon shape is obtained as shown in Figure 7. This shows that the concept of a regular hexagon flat structure can be taught with a nyiru context woven approach. In addition to the woven hat, the mathematical idea used is a multiple of 12 for the number of first leaves, also the concept of division with 12 , for example leaves must be 12 because each corner requires 2 leaves. Here, it can be seen that besides calculating leaves in multiples of 12 , there is also the idea of division or multiplication, if 6 corners means 12 leaves because $6 \times 2=12$.

The pattern above shows that the pattern on woven nyiru can be used to teach the concept of dilatation of a flat plane with the initial shape is a hexagonal hexagonal. If the pattern is observed, the scale used is the width of the leaf in the form of a parallelogram, the distance of one hexagonal to another is determined by the number of parallelogram shapes of the cabbage (koli) leaves. If analyzed more deeply the mathematical concepts in the structure of nyiru woven can be seen that for hexagonal dilatation patterns that are visible from the basic form of nyiru, can be constructed as mathematical formula.

In addition to the form of dilation, the motif on nyiru woven can be related to the concept of tiling or tessellation Based on the search results, it can be seen that since their ancestors in the Tutuwaru community, the primitive mathematical ideas were known even though they did not call it mathematics.

If you pay attention to the structure of the matting made by the Tutuwaru community, it can be said that the mathematical ideas of tapping have been owned by the community since their ancestors as primitive or indegious knowledge. Mathematical concepts that emerge are known as regular tesrelation. According to (Harris, 2000) Tessellations in which one regular polygon is used repeatedly are called regular tessellations. One of the regular shapes of the thesis is a equilateral triangle where there are 6 triangles with an angle of 600 each meeting at one point. Thus the number of angles around the meeting point is 3600 as stated in Haris (2000) as in the following figure.

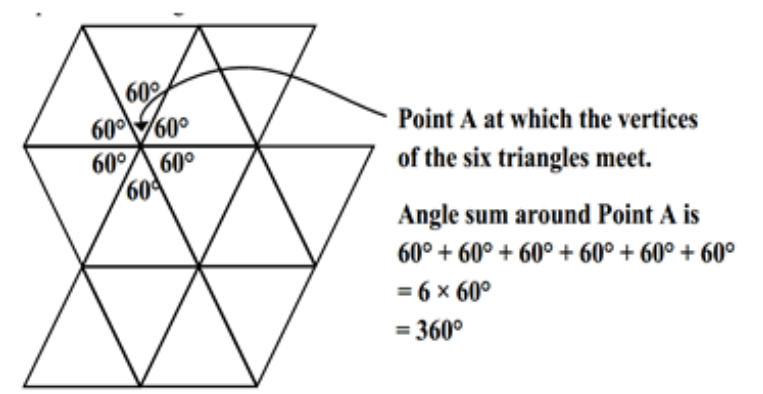

Figure 8. The basic form of tessellation with isosceles triangle

If the basis of the tessellation is developed it will form a hexagon flat structure, which is similar to the nyiru woven structure made by the Tutuwaru community in the following.

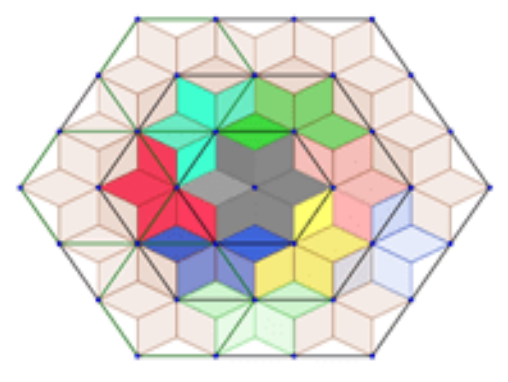

Figure 9. The form of the tessellation is woven nyiru

Other mathematical ideas that can be learned in the structure of mistaken woven are parallel lines, vertices, triangles and hexagons. If you count the number of parallelograms that make up the blueprint from the bottom, you can find a number pattern.

Besides nyiru, the Tutuwaru people also weave hats as a tool used to cover their heads when working in the garden or walking. To make the head part of the hat, after placing the base of the plait, a circular weaving method is carried out by 
folding the leaves to form milk to surround the hexagon-shaped base of the plait. In order to woven hats, if the matting follows the shape of a hexagon until it ends with 6 angular points in the form of a right angle, how to weave it to form a hexagon shape with a rectangular pattern of counting $1 \mathrm{in}, 2$ out, 1 in 2 out so The calculation patterns created are $1,2,1,2, \ldots$ up to 1 . The following is a picture of some of the structures of woven hat structures.



Figure 10. Advanced woven structure

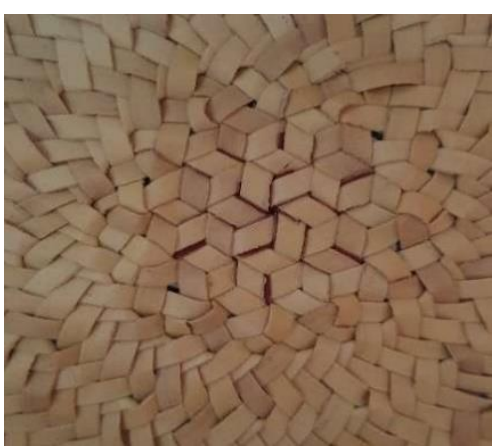

Figure 11. Basic woven structure

Mathematical ideas that emerge are rectangles, right angles, and perpendicular concepts. In Figure 10 it appears that when the basic weaving is formed, it is then thought to form a circle by changing the pattern of woven into 1 in 2 out and weaving in a circle. In relation to mathematics, the mathematical concept that has always existed is the concept of a circle, this can be seen in the word "circumference" of the bone. In the process using patterns $2,1,2,1, \ldots$ and so on.

The woven structure of the hat is tessellated with its basic shape is a rectangle, arranged on each side and forming a right angle with the following pattern:



Figure 12. Rectangular tessellation in woven hats
This tessellation is called as a correlation with the basic shape of a quadrilateral and is included in the regular tiling because it is formed by many regular facets. The patterns that can be seen in the above correlation picture above are parallel lines, perpendicular lines and right angles.

By paying attention to the pictures above it can be seen the relationship between woven patterns and motifs with mathematical concepts, for example in sesre or baskets exist the concept of building tubes with a circular or elliptical basis as well as variations of images on blanket-shaped parallelogram tubes.

The patterns on the woven cabbage show that the community's thought processes have been inspired by mathematical ideas. The process of thinking in making these patterns is primitive knowledge, which is passed down from generation to generation in the family. This is because the making of these webbing is a skill that is used to get equipment used daily. This skill is a traditional local knowledge that is unique and exists and develops around certain indigenous groups of women and men in a certain geographical area (Grenier, 1998; Hadi, 2006). This is in accordance with the culture of the Tutuwaru community where the nyiru woven and hat craftsmen are dominated by women and the basket craftsmen are dominated by men.

\section{Conclusion}

The knowledge of primitive communities in constructing various natural resources around them to maintain their lives is obtained in the lives of the Tutuwaru people who live in communities that are barely reached by transportation and communication access. Through a study of cultural products related to the mathematical concept in Koli leaf weaving, which is a basic ingredient, shows high ability of that community in creative thinking. This creative thinking brings up woven patterns and shapes that can be used to embed mathematical concepts such as geometry and numbers. The geometry concepts studied are points, lines, alignment, perpendicularity, vertex, and the shape of the correlation or change. In addition, the concept of a circle, and parallelogram can also be seen in the form of woven. The patterns of numbers that can be known are multiples of 6 , numbers $1,2,1,2, \ldots$ and $1,3,1,3, \ldots$.

This study shows that the knowledge of local communities needs to be further studied to find a variety of knowledge that can be used as local 
wisdom for the development of student character and schools' subjects.

\section{References}

Francois, Karen. (2009). Tle of Etnomathematics within Mathematics Education, Procceeding of CERME6. tersedia pada www.inrp.fr/editions/cerme6, download pada tanggal 20 Maret 2017.

Grenier Louise. (1998). Working with Indigenous Knowledge: A guide for Researchers. Ottawa: IDRC.

Hadi,A.C.Sungkana. (2006). Melestarikan Kearifan Lokal masyaralkat Tradisional, Buletin Perpustakaan dan Informasi Bogor, tersedia pada http://bpib-

art.blogspot.com/2006/06/melestarikan-

kearifan-masyarakat.html, diunduh, 9 Februari 2019,

Hadi, S. (2017). Pendidikan Matematika Realistik. Radjawali Pers, Jakarta.

Hartoyo, A. (2012). Eksplorasi Etnomatematika pada Budaya Masyarakat Dayak Perbatasan Indonesia Malaysia Kabupaten Sanggau Barat. http://jurnal.upi.edu/file/3-agung.pdf, diakses 20 Maret 2017.

Harris, A. (2000). The Mathematics of Tesselation. Available at https://studylib.net. didownload 9 Februari 2019

Isabela, M. C. (2019). Etnomatematika sebagai salah satu bentuk penguatan kearifan local dalam pembelajaran matematika, MATH DIDACTIC: JURNAL PENDIDIKAN MATEMATIKA Volume 4 Edisi Dies Natalis XXXII, halaman $243-252$ Tersedia Daring pada http://jurnal.stkipbjm.ac.id/index.php/math

Laurens, Th. (2016) Analisis Etnomatematika dan Penerapannya Dalam Meningkatkan Kualitas Pembelajaran, Journal LEMMA, e-ISSN 24601047, Volume 3 No.1, STIKIP PGRI Sumatera Barat, Padang.

Marsigit. (2016). Pengembangan Pembelajaran Matemati ka Berbasis Etnomatematika, Makalah dipresentasikan pada Seminar Nasional Matematika dan Pendidikan Matematika 2016, STIKIP PGRI Sumatera Barat

Matitaputy. (2016). Desain Pembelajaran Matematika dengan Pendekatan Etnomatematika pada Materi Nilai Tempat Kelas 2 SD, Journal LEMMA, eISSN 2460-1047, Volumen 3 No.1, STIKIP PGRI Sumatera Barat, Padang

Mampouw. (2010). Eksplorasi Konsep Dasar Matematika Melalui Konteks Lokal dan Penggunaannya dalam Pembelajaran, Prosiding Konferensi Nasional Matematika V, Universitas Negeri Manado, ISBN 978-602-96426-1-2, hal.413-422

Matang Rex. (2002). The Role of Etnomatematics in Mathematics Education in Papua New Guine: Implications for Mathematics Curriculum, Journal of Educational studies vol. 24, Juni 2002, download 20 Maret 2016.

Ngilawajan, D. A. (2015). Konsep Geometri Fraktal Dalam Kain Tenun Tanimbar. BAREKENG: Jurnal Ilmu Matematika Dan Terapan, 9(1), 3339. Retrieved from https://ojs3.unpatti.ac.id/index.php/barekeng/arti cle/view/277

Rosa, M \& Orey, D. (2011). Ethnomathematics: the cultural aspects of mathematics, Revista Latinoamericana de Etnomatemática Vol. 4 No.2,32-54, tersedia pada http://dialnet.uniroja.es>articula, download, 13 Maret 2016

World Bank. (2016). Meningkatkan kualitas Pendidikan di Indonesia, Materi Presentase pada Rakor Sergur, 22 Maret 2016, Kantor Kemendikbud, Jakarta, Tidak dipublikasikan

Zusmelia. (2016). Matematika dalam Perspektif Indegenous People dan Indegenous Knowledge, Makalah disajikan dalam Seminar Nasional Pendidikan Matematika 2016, STIKIP PGRI Sumatera Barat, Padang.

Zhang Weizhong \& Zhang Qinqiong. (2010). Etnomathematics and Its Integration Within the Mathematics Curriculum, Journal of Mathematics Education, June, Vol.3.No.1.pp.151-157, download, 15 Maret 2016. 